\title{
LARVICIDAL CONSEQUENCES AND PHYSICAL CHANGES FOLLOWING THE UTILITY OF SOME PETROCHEMICAL FUELS IN EMBALMING SERVICES
}

\author{
Sunday O. Popoola \\ Department of Anatomy, Ekiti State University, Ado-Ekiti, Nigeria
}

\begin{abstract}
An ideal embalming fluid: eliminates infection and health hazards; maintains ante-mortem appearance; eliminates sequence of decomposition; prevents occupation of larvae and fungi. No embalming formulae had met these attributes, hence, the quest to formulate an ideal embalmment fluid across the globe continues with the present study designed to hypothesize the larvicidal consequences and physical changes following addition of some petrochemical fuels to common embalming fluid using Wistar rats under bioethics standard. An embalmment composition was propounded with Group A (Control) having $75 \%$ of the composition along with $25 \%$ of sterile water. Groups B, C and D having $75 \%$ of the composition with $25 \%$ of kerosene, petrol and diesel respectively. First stage: embalmment of two rats per group and monitoring for 12 weeks for physical changes. Second stage: delayed embalmment by immersion of one rat per group that was occupied by larvae in different embalming mixtures and death rate monitored to assess larvicidal consequences of the mixture. Analysis donewith Statistical Package for Social Sciences (versión 25) and the hypotheses were tested at 0.05 level of significance. The mean fluid needed to embalm $1 \mathrm{~g}$ of tissue was $0.6 \pm 0.04 \mathrm{ml}$. Retainment of ante-mortem weight was highest in Diesel-mixture after 12 weeks of embalmment. Petrol-mixture killed all the larvae within 60 seconds while others had nolarvicidal effect per se. Petrol-mixturewas best in damping offensive odour from necrotic tissue. Diesel-mixture conferred lustre beauty on the integumentary system. Petrol-mixture had unambiguous larvicidal effect. This study was veritably 'Evidence Based Anatomy' with the innovative outcomes in embalming affairs.
\end{abstract}

Keywords: Petrochemical fuels; Embalmment; Anatomy; Larvicidal consequences

\section{RESUMEN}

Un fluido de embalsamamiento ideal: elimina las infecciones y los riesgos para la salud; mantiene la apariencia ante-mortem; elimina la secuencia de descomposición; previene la ocupación de larvas y hongos. Ninguna fórmula de embalsamamiento había cumplido con estos atributos, por lo tanto, la búsqueda para formular un fluido de embalsamamiento ideal en todo el mundo continúa con el presente estudio diseñado para hipotetizar las consecuencias larvicidas y los cambios físicos tras la adición de algunos combustibles petroquímicos al fluido de embalsamamiento común utilizando ratas Wistar bajo bioética estándar. Se propuso una composición de embalsamamiento con el Grupo A (Control) que tenía el $75 \%$ de la composición junto con el $25 \%$ de agua estéril. Los grupos B, C y D tienen $75 \%$ de composición con $25 \%$ de keroseno, gasolina y diesel respectivamente. Primera etapa: embalsamamiento de dos ratas por grupo y seguimiento durante 12 semanas para detector cambios físicos. Segunda etapa: embalsamamiento retrasado por inmersión de una rata por grupo que estaba ocupado por larvas en diferentes mezclas de embalsamamiento y se monitoreó la tasa de mortalidad para evaluar las consecuencias larvicidas de la mezcla. El análisis se realizó con el paquete estadístico para ciencias sociales (versión 25) y las hipótesis se probaron con un nivel de significancia de 0.05 . El líquido medio necesario para embalsamar $1 \mathrm{~g}$ de tejido fue de 0,6 \pm $0,04 \mathrm{ml}$. La retención del peso ante-mortem fue mayor en la mezcla de diesel después de 12 semanas de embalsamamiento. La mezcla de gasoline mató a todas las larvas en 60 segundos, mientras que otras no tuvieron ningún efecto larvicida per se. La mezcla de gasolina fue la mejor para amortiguar el olor ofensivo del tejido necrótico. La mezcla de diesel confería belleza lustre al sistema tegumentario. La mezcla de gasoline tuvo un efecto larvicida inequívoco. Este studio fue verdaderamente "Anatomía basada en evidencia" con los resultados innovadores en asuntos de embalsamamiento.

Palabras clave: Combustibles petroquímicos; Embalsamamiento; Anatomía; Consecuencias larvicidas

* Correspondence to: Sunday Ogunsuyi Popoola. ogunsuyipopoola@gmail.com

Received: 10 May, 2021. Revised: 27 May, 2021. Accepted: 28 May, 2021. 


\section{INTRODUCTION}

Understanding the various embalming techniques from ancient days to present time is desirable to analyzing science and progress of embalmment. Ancient preservation of bodies started in Egypt by accidental natural means of sand and air drying of human and animal remains by the bank of Nile River which later culminated properlyinto the authenticated mummification (Brenner, 2014). Mummification is a process of eliminating all the available moisture from the dead thereby leaving a dried specimen having a great resistance to decay. Basically then artificial means of preservation initiated with use of physical means and chemical (Natron) obtained from part of Nile River containing active ingredient of concentrated Sodium carbonate decahydrate solution were employed in mummification in many Egyptian dynasties, and in the north of Chile and Southern Peru, the Chinchorro embalming had other ways of being practiced such as fleshing, evisceration, preservation of the skin and the use of clay rich in arsenic which was postulated as a preservative (Johnson et al., 2012; Marquet et al., 2012). Aside Natron, chemical compositions from herbs and shrubs, cedar oil, tree resins, gums and tar were used for embalmment whereas honey or wax was specially employed for preservation of Alexander the Great following his death in a battle in $323 \mathrm{BCE}$ by submerging while transporting his body from Babylonia to his founded home, Alexandria, the capital of ancient Egypt (Sharquie and Najim, 2004; Staff, 2013).

At renaissance, the rapid development in science accomplished improvement in embalmment for anatomic dissection and teaching with injection of toxic and non-toxic chemicals into hollow and other parts of the body. Ultimately, injection into different parts of cardiovascular system was practiced using materials including: warm and cold water, wax and mercury (McKone, 1999). Progress in embalmment was facilitated by arterial injection and by 19th century tremendous achievement was recorded following discoveries in Chemistry. Scientists in Europe including Williams Hunter, John Hunter and Matthew Baillie capitalized on the development in arterial injection and they applied different types of oil, powders and resins with potentials to preserve biological specimen (Trompette and Lemonnier, 2009). Guiseppe Tranchina, an Italian Anatomist from Naples successfully utilized arsenic compositions for embalmment with the body getting completely dried in six weeks (Staff, 2013). Nevertheless, it is suggested to improve the orthography of the names and the general drafting, Alfredo Salasia and Edmond Souchon were amongst the pioneers who had embalming compositions with formaldehyde and perhaps carbolic acid (Piobino-Mascali et al., 2009).

Contemporarily, embalmment is categorized into anatomical and funeral. The anatomical embalmment is carried out to ease dissection, prosection, exhibition, diagnostic, therapeutic, research and other learning purposes while the funeral embalmment is purely done to preserve the body for proper burial rites and disposal. In the recent time, Gunther von Hagens originated and popularized plastination of which lipids dissolves with acetone as a newer means of embalmment involving dehydration, forced impregnation and curing in replacement of body water and lipids with curable low viscous polymer, for instance, silicon (Martinez, 2012).

These days, efforts are being made towards formulation of an ideal embalming fluid possessing the following characteristics: absent risk of infection; guaranteeing ante-mortem appearance; reducing sequence of decomposition (autolysis, putrefaction and decay); prevent occupation of insects and maggots; and prohibiting growth of fungi on the bodies. With these properties, the following composition is crucial: preservatives, germicides, buffers, wetting agents, anticoagulants, dyes, vehicles and perfumes (Ajmani, 1998). All these chemicals are used in various combinations depending on the age, sex, surface area, autopsied, nonautopsied, dehydration, obese, refrigeration, decomposition, cause of death, timing of death and purpose of embalmment. Albeit, death will always make the body change no matter how expert the embalmers' skills are in addition to post-mortem reconstructive surgeries carried out following traumatic and other aetiologies of death, no single embalming composition has been able to achieve all the afore-mentioned attributes, hence, the quest to continuing searching for the ideal embalming fluid from one part of the globe to another.

Petrochemicals are hydrocarbons derived from crude oil through the physical process of fractional distillation to maintain alkanes of similar boiling points. Toxicity of petrochemicals follows general rule: depends on biological species, concentration of chemical and period of exposure. In terms of viscosity, that of kerosene is less than that of diesel but higher than that of petrol. However, viscosity of diesel is higher than that of water. petrol otherwise called gasoline is utilized widely as jet fuel (Curl and O'Donnell, 1977). Diesel is equally used widely by heavyduty vehicles (trains, trucks) and generating plants. The use of petrochemical fuels in tissue preparation cannot be considered unusual following the mixture of kerosene (aliphatic hydrocarbon) and xylene (aromatic hydrocarbon) 
as clearing agents with innovative outcome (Ofusori et al., 2009).

By chance, so to say, from the use of petrochemical creams/oils in external dressing of bodies needing special embalmment in our mortuary, it was discovered that incorporation of petrochemical fuels to embalming fluid preserves bodies better. Petrochemicals are added in turbulent manner (Stapountzis et al., 1991) to embalming fluid meant for decomposing bodies, traumatized bodies (ante- or post-mortem), drowned bodies, and those bodies that are considered for restoration of parts, long-distance transportation and already decaying bodies with occupation of flies and their larvae. Besides addendum is sometimes carried out on special request by the relations/relatives of the dead, perhaps, based on their experiences with our embalming services. Petrochemicals do not only help in killing the larvae but equally driving the flies away. On account of these observations and inquisitions, and for the fact that the quest for an ideal embalmment mixture still continues across the globe, this research work was designed to qualitatively and quantitatively investigate the larvicidal consequences of some common petrochemical fuels (kerosene, petrol and diesel) as addenda to embalming fluid on bodies or carrion using Wistar rats as proxies for humans. A scientific assumption was then conjectured: Null hypothesis $\left(\mathrm{H}_{0}\right)$; addition of some petrochemical fuels to common embalming fluids has neither larvicidal consequences nor physical changes (general body weight and skin colour) on embalmed Wistar rats. Alternate hypothesis
$\left(\mathrm{H}_{1}\right)$ : addition of some petrochemical fuels to common embalming fluids has both larvicidal consequences and physical changes (general body weight and skin colour) on embalmed Wistar rats.

In order to justify this study, utility of some petrochemical fuels of this manner in embalming affairs using Wistar rats will serve as a guide in extrapolating the beneficiary effects on human remains, thereby, providing objective measurement for acceptance by various producers of embalming chemicals and allow for comparison of results among other researchers (Bosze and Houdebine, 2006). Researches on the possible consequences of petrochemical fuels on different aspects of embalmment using Wistar rats are very few: this study was then designed to bridge any communication gap in the scientific knowledge.

\section{MATERIALS AND METHODS}

Experiment conducted in two stages at the Department of Anatomy Complex of Ekiti State University, Ado-Ekiti, Nigeria. Because ethical approval was not feasible for some reasons including industrial action by the institution academics, the research was conducted according to the relevant regulations in strict recommendations of the National Institute of Health's Guide for the Care and Use of Laboratory Animals. A coverage permission was however granted in the department.

\begin{tabular}{|l|c|c|}
\hline Composition & Embalming chemical & Percentage (\%) \\
\hline Preservative/Germicidal & Formaldehyde & 3.0 \\
\hline Preservative/Diluent/Germicidal & Methanol & 20.0 \\
\hline Diluent/Bactericidal & Normal Saline & 10.0 \\
\hline Germicidal/Preservative & Phenol & 1.0 \\
\hline Wetting agent/Lubricant & Glycerin & 0.5 \\
\hline Anticoagulant & Sodium Citrate & 0.5 \\
\hline Diluent/Vehicle & Water & 65.0 \\
\hline Total & & 100.0 \\
\hline
\end{tabular}

Table 1: Modified common embalming composition (CEC). 


\begin{tabular}{|c|c|c|}
\hline Group & $\begin{array}{l}\text { Percentage (\%) of common } \\
\text { embalming composition (CEC) }\end{array}$ & $\begin{array}{c}\text { Percentage }(\%) \text { of Petrochemical } \\
\text { fuel }\end{array}$ \\
\hline & from Table 1 & \\
\hline A (Control) & 75 & 25 of distilled water \\
\hline B (Kerosene) & 75 & 25 of Kerosene \\
\hline C (Petrol) & 75 & 25 of Petrol \\
\hline $\mathrm{D}$ (Diesel) & 75 & 25 of Diesel \\
\hline
\end{tabular}

Table 2: Embalming mixture with petrochemical fuel

Putting rats to death was performed using chloroform (tetrachloromethane $\mathrm{CCL}_{4}$ ) in cotton wool in an enclosure for 2-3 minutes as inhalational anaesthetic agent and followed by cervical dislocation to minimize suffering. Principles outlined in the Declaration of Helsinki were equally complied with. Four groups were designed with 12 Wistar rats (albino rats) in all. Embalming fluid based on surface area of Wistar rat was constituted as in Table 1 and 2. Note that in order to avoid the mixture being phased out (made the mixture in constant agitation), since these petrochemical fuels are hydrophobic, the mixture was always under constant stirring. Besides, injections were delivered in turbulence manner to further avoid phasing out of the mixture and enhance better diffusion of the mixtures. The exercise was conducted in two stages. In the first stage (8 rats used): two rats per groups of $A, B, C$ and $D$ for cavity and supplemental methods of embalmment (hypodermic and surface) according to Ajmani (1998); and in the second stage (4 rats): one rat per groups of A, B, C and D for larvicidal consequences. The set up was demonstrated and witnessed by independent observers drawn from other departments of our college of medicine.

All the rats were males and initial weights taken before embalmment. Since the use of fuels derived from petroleum is risky for the health of human operators (tremendously harmful to health) both through the inhalation route and through the skin, Universal Basic Precaution (UBP) needed in handling petrochemical fuels were strictly observed (Guild, 2008). The fact that petrochemical fuels, broadly, destroy personal protection items (gloves, laboratory outfits amongst others) and also can cause topical burns: our local precautionary measures since inception of our laboratory and UBP were further strictly adhered to.

First stage (immediate embalmment): This was performed immediately after the rats were put to death. Two (2) rats per group were labeled and embalmed homogenously by injection into cavities, hypodermal layer and surface (topical or directly rubbing on the skin) techniques according to body size using hypodermic size 19G-needle and syringe in turbulence manner since petrochemical fuels being hydrophobic are not mixable with water and alcohol while the mixtures were under constant stirring. Each of the embalmed rats had another measurement of weight to determine amount of fluid needed for embalmment. The weight and other physical changes of embalmed rats were monitored weekly for twelve weeks.

Second stage (delay embalmment): There was a delay in embalmment at this stage: embalmment was performed three days after the rats were put to death and left in the same environmental condition at the laboratory experimental room with no restriction of insects in order to allow occupation of their larvae. On the third day of exposure, the dead rats had occupation of larvae (more than 200 in number per rat using hand lens for a better viewing and counting). The embalmment was carried out on the third day with assistance of trained embalmers by submersion of larvae-occupied rats in separate bowls containing different mixtures as constituted in Table 2. Timing was recorded using stopwatch in monitoring death rate of the maggots/larvae qualitatively. Larvae-occupied rats were later disposed by soil burial after assessing larvicidal effects of embalmment mixtures.

Results collated and entered into Statistical Package for Social Sciences (IBM SPSS version25) and the hypotheses were tested at 0.05 level of significance within confidence interval of $95 \%$. 


\section{RESULTS}

Amount of fluid needed for embalmment was as shown in ' $Z$ column' of Table 3 . Since density of water is equal to $1 \mathrm{~g} / \mathrm{ml}$, the value of fluid needed is also equal to the difference in final weight ' $Y$ ' (after embalmment) and initial weight ' $X$ ' (before embalmment). Table 4 showed the percentage of weight retained after 12 weeks of embalmment: $35.3 \%, 41.7 \%, 36.1 \%$ and $50.2 \%$ for Groups A, $B, C$ and $D$ respectively. Lustre effect was observed on rats in Group D throughout the 12 weeks. Equally, suppression of fungal growth was observed qualitatively amongst rats in Group D.

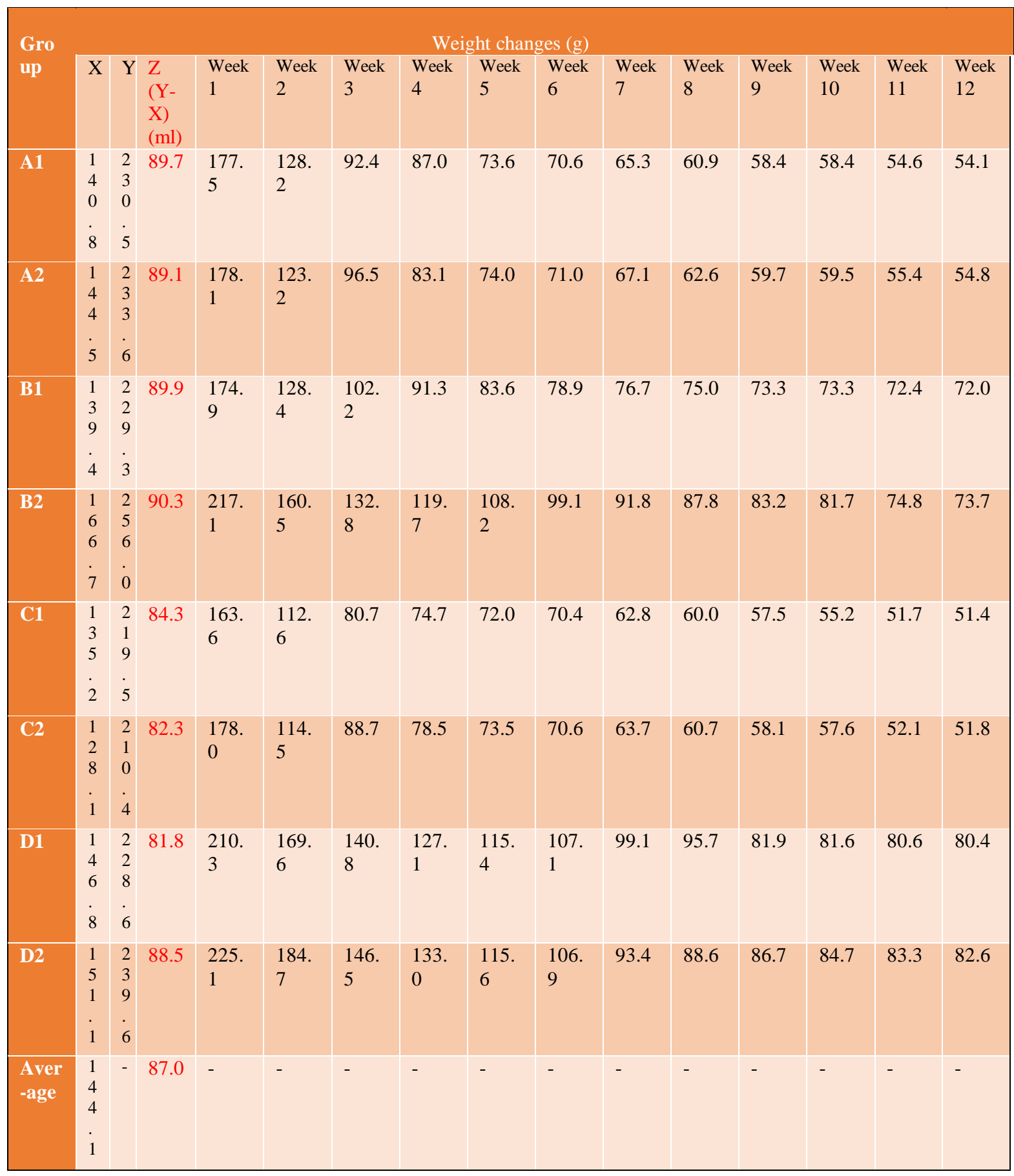

Table 3: Weight changes with petrochemical fuel embalmment mixture. $\mathbf{A}=$ Control, $\mathbf{B}=$ Kerosene mixture, $\mathbf{C}=$ Petrol mixture, $\mathbf{D}=$ Diesel mixture, $\mathbf{X}=$ Weight before embalmment (Original weight), $\mathbf{Y}=$ Weight after embalmment, $\mathbf{Z}=\mathbf{X}-\mathbf{Y}$ (Amount of embalmed fluid in $\mathrm{ml}$ of water since density of water is $1 \mathrm{~g} / \mathrm{ml}$ ) 
The hypothesis test theory (Table 3b) in which $p$ was less 0.05 rejected null hypothesis showed that all the various weight changes amongst the groups were independent. Larvicidal (antimaggot) effect of embalmment mixture was demonstrated in Table 5 with petrol mixture having a significant mortal effect on the larvae of more than 200 in number per group.Descriptive statistics on amount of fluid needed for embalmment in Table 3a was = Average amount of fluid needed in $Z$ column/Average weight of $X$ column $=87.0 \mathrm{ml} / 144.1 \mathrm{~g} \approx 0.6 \pm 0.04 \mathrm{ml} / \mathrm{g}$. Therefore, mean of fluid needed to embalm $1 \mathrm{~g}$ of rat tissue was $0.6 \pm 0.04 \mathrm{ml}$.

At 12 weeks post embalmment, observation showed no growth of fungi (yeast) amongst the rats embalmed with diesel mixture. Besides lustre beauty on the in tegumentary system of rats embalmed with diesel was equally noted by independent observers.

\begin{tabular}{|c|c|c|c|c|c|c|c|c|c|c|c|c|c|c|}
\hline \multirow[t]{4}{*}{ Group } & \multicolumn{12}{|c|}{ Post embalmment retained weight (\%) } & \multirow{2}{*}{$\begin{array}{l}\text { ARW } \\
\text { per }\end{array}$} & \multirow{2}{*}{$\begin{array}{l}\text { ARW } \\
\text { per }\end{array}$} \\
\hline & $\mathrm{Wk}$ & Wk & Wk & Wk & Wk & Wk & Wk & Wk & Wk & Wk & Wk & Wk & & \\
\hline & 1 & 2 & 3 & 4 & 5 & 6 & 7 & 8 & 9 & 10 & 11 & 12 & rat & group \\
\hline & & & & & & & & & & & & & $(\%)$ & $(\%)$ \\
\hline A1 & 77.0 & 55.6 & 40.1 & 37.7 & 31.9 & 30.6 & 28.3 & 26.4 & 25.3 & 25.3 & 23.7 & 23.5 & 35.45 & 35.3 \\
\hline A2 & 76.2 & 52.7 & 41.3 & 35.6 & 31.7 & 30.4 & 28.7 & 26.8 & 25.6 & 25.5 & 23.7 & 23.5 & 35.14 & \\
\hline B1 & 76.3 & 56.0 & 44.6 & 39.8 & 36.5 & 34.4 & 33.4 & 32.7 & 32.0 & 32.0 & 31.6 & 31.4 & 40.06 & 41.7 \\
\hline B2 & 84.8 & 62.7 & 51.9 & 46.8 & 42.3 & 38.7 & 35.9 & 34.3 & 32.5 & 31.9 & 29.2 & 28.8 & 43.32 & \\
\hline $\mathrm{C} 1$ & 74.5 & 51.3 & 36.8 & 34.0 & 32.8 & 32.1 & 28.6 & 27.3 & 26.2 & 25.1 & 23.6 & 23.4 & 34.64 & 36.1 \\
\hline $\mathrm{C} 2$ & 84.6 & 54.4 & 42.2 & 37.3 & 34.9 & 33.6 & 30.3 & 28.8 & 27.6 & 27.4 & 24.8 & 24.6 & 37.54 & \\
\hline D1 & 92.0 & 74.2 & 61.6 & 55.6 & 50.5 & 46.9 & 43.4 & 41.9 & 35.8 & 35.7 & 35.3 & 35.2 & 50.67 & 50.2 \\
\hline D2 & 93.9 & 77.1 & 61.1 & 55.5 & 48.2 & 44.6 & 39.0 & 37.0 & 36.2 & 35.4 & 34.8 & 34.5 & 49.77 & \\
\hline
\end{tabular}

Table 4: Weight change rates due to petrochemical fuels embalmment mixture. ARW Average Retained Weight, Wk Week, A Control with $35.3 \%$ retainment of original weight, B Kerosene mixture with $41.7 \%$ retainment of original weight, CPetrol mixture with $36.1 \%$ retainment of original weight, D Diesel mixture with $50.2 \%$ retainment of original weight

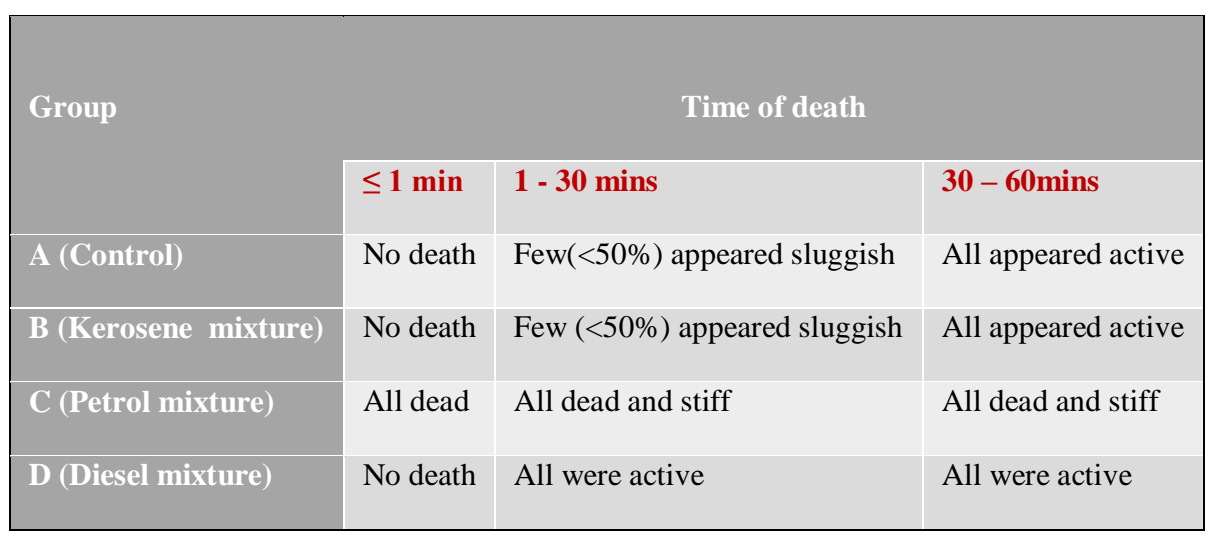

Table 5: Larvicidal effect ofmixture of petrochemical fuels plus common embalmment fluid. There was qualitative drastic damping of offensive odour from Group C compared to others as observed by some staffs of Anatomy Department and recruited independent observers to eliminate bias. 


\section{DISCUSSION}

The utility of petrochemical fuels in embalmment on Wistar rats served as a guide in extrapolating their effects on human remains, thereby, providing objective measurement for acceptance by various embalming centres and allow for comparison of results amongst other researchers while applying all the necessary universal basic precautionary measures in handling chemicals (Bosze and Houdebine, 2006).

The amount of fluid needed to embalm $1 \mathrm{~g}$ of rat's tissue was approximately $0.6 \mathrm{ml}$ as against varying value of $0.2 \mathrm{ml} \quad(22.7 \mathrm{~kg}$ for $3.8 \mathrm{~L}$ equivalence of $1 \mathrm{~g}$ to $0.2 \mathrm{ml}$ ) for human embalmment according to popular documentation from a renowned embalmer called Seiple (2009). Even though both human and rat belong to the class of Vertebrata called Mammalia, this variability might be based on the fact that the subcutaneous fat in the integumentary system of modern hairless Homo sapiens loquens requires less of embalming fluid compared to evolutionary ever furry albino rats of little or no fat at the subcutaneous layer. On account of this, (0.6/0.2) would produce asimple arithmetic ratio 3 to 1 of rat to humanas the order of embalming fluid calibration while extrapolating this present experimental animal model as a practicable proxy to humans in this locality.In a nutshell, one gram of rat tissue would require triple amount of embalming fluid needed for one gram of human tissue and vice versa.

One of the doggedness of embalmment is to maintain an ante-mortem anatomical structures to as much as possible following death. Table 3 of this study had an evaluation of the weight changes per week after embalmment for an arbitrary period of 12 weeks ( 3 months). It was discovered that in the order of weight retained: Diesel-mixture retained the highest weight after the draining towards mummification or skeletonization period. The physical properties of petrochemical fuels vis-à-vis viscosity, density, volatility and lubricationin which the comerciallyless expensive hydrophobic diesel was the best instead of utilizing the more commerciallyexpensive hydrophilic glycerin (having similar physical properties with diesel) might be responsible for the attribute of weight retention (Curl and O'Donnell, 1977; Christoph et al., 2006). In another discovery, the best lubricant property of diesel out of the three petrochemical fuels might be responsible for lustrous auburn waves on the integument of the rats.

The larvicidal consequences of the various embalming mixtures were noted in Table 5. In all, embalming mixture with petrol seemed to have gotten absolute deadly effect on thelarvae/ maggots thereby making this mixture the best of all the three in delayed embalmment with accompanied decaying of soft tissue. This promising attribute of petrol-mixture thereby identifies it to be an ideal agent for embalmment of any bodies that are occupied with larvae and insects for one reason or the others following death while observing universal basic precautionary measures in handling chemicals (Guild, 2008). However, damping of offensive odour, perhaps, due to perceived toxic effect on microorganisms from necrotic tissue as observed best in petrol-mixture was another innovative attribute of petrochemical fuels in embalmment affairs. It was possible the deadly effect of petrolmixture on the larvae might have been due to direct asphyxiating toxic action on tissues; extrapolated ascomplete cessation of activities of the three vital and interdependent organ systems, viz respiratory, nervous and cardiovascular medically described as clinical death (Bernat et al., 2010). Broadly speaking from qualitative and quantitative assessment of various actions of the three petrochemical fuels, the effects of embalming mixture containing kerosene were observed to be sandwiching that of petrol and diesel.

Having gone through the articles on debate coordinated globally by Biasutto on the plausive use of human bodies in teaching anatomy, this present study with the petrochemical fuel mixtures' affirmed toxic effects on larvae, chasing away of insects, damping of offensive odours amongst others may be a good conception towards acquisition of more cadavers for dissection, prosection, diagnostics, therapeutics, exhibition and other related researches (Biasutto et al., 2014). The singular limitation of rejecting bodies with active infection in Argentina and perhaps other countries alike may be a thing of the past with advancement (more studies) in the use of petrochemical fuels as addenda to common embalming fluids. The advancement may aid elimination of associated health hazards from active or indolent form of infection with resultant plenteous of cadavers in anatomical sciences.

In conclusion, using rat as practically-available proxy for humans, all the various mixtures were found useful in embalmment for different purposes while obeying universal basic precautionary measures in handling of petrochemical fuels and other chemicals. Embalming mixture with diesel was the best in retaining antemortem weight to as much as possible for a long period of time. Embalming mixture with petrol had an absolute larvicidal effect and reduced insect occupation. Besides petrol-mixture was the best in damping offensive odour from putrefying 
necrotic tissues. Embalming mixture with diesel demonstrated the lustre beauty on the integumentary system by its lubricating property. In a nutshell, embalming mixture with petrol is hereby recommended for embalmment of any bodies with insects and larvae occupation while that of diesel is recommended where and when there are needs for retainment of gross anatomical structures to as much degree of antemortem periodas possible. In all, effects of kerosene mixture sandwiched that of petrol and diesel. Suggestively, more studies on the usefulness of petrochemical fuels in embalming affairs are highly appreciative.

\section{Conflict of Interests \\ None.}

\section{Funding}

This research did not receive any specific grant from funding agencies in the public, commercial, or not-for-profit sectors.

\section{Ethical Approval}

Duly approved by ethical and clearance committee of the institution.

\section{Informed Consent}

Not available.

\section{AKNOWLEDGEMENTS}

Mr OgundeleA E, Mr Adeleke A $\mathrm{M}$ and $\mathrm{Mr}$ Arowolo F I, embalmers of the Department of Anatomy, Ekiti State University, Ado-Ekiti, Nigeria were specially appreciated for their unparalleled roles in making this experimental study a reality. The recruited independent observers were equally appreciated.

Importantly, the Argentine Journal of Clinical Anatomy (RAAC) requires acknowledgement to people who voluntarily donate their bodies for teaching and science. On this note, the magnanimity of cadavers and voluntary body donors towards anatomy and other related disciplines are highly treasured.

\section{REFERENCES}

Ajmani ML. 1998. Embalming chemicals and Fluids. In: Embalming Principles and Legal Aspects. Jaypee Brothers Medical publishers. India, 111-30.
Bernat JL, Bratton SL, Gries CJ, Rushton CH. 2010. The circulatory-respiratory determination of death in organ donation. Critical Care Medicine 38: 963-70.

Biasutto SN, Sharma N, Weighlein AH, Benia FM, McBride J. 2014. Human bodies to teach anatomy: importance and procurement experience with cadaver donation. Rev Arg de Anat Clin 6: 72-86.

Bosze Z, Houdebine LM. 2006. Application of Rabbits in Biomedical Research: A review. World Rabbit Science 14: 1-14.

Brenner E. 2014. Human body preservation - old and new techniques. J Anat 224: 316-44.

Christoph R, Schmidt B, Steinberner U, Dilla W, Karinen R. 2006. Glycerol. Ullmann's Encyclopedia of Industrial Chemistry. Ullmann's Encyclopedia of Industrial Chemistry. doi:10.1002/14356007.a12_477 (Accessed June 2020).

Curl H, O'Donnell K. 1977. Chemical and physical properties of refined petroleum products. Marine Ecosystems Analysis Program Boulder, Colorado. National Oceanic and Atmospheric Administration Technical Memorandum ERL MESA- 17: 6-14.

Guild S. 2008. IAEA Safety Standards Core Management and Fuel Handling for Research Reactors. International Atomic Energy Agency. Vienna, 24-28.

Johnson EC, Johnson GR, Johnson M. 2012. The origin and history of embalming. In: Mayer RG, editor. Embalming-History, Theory, and Practice. New York: McGraw-Hill, 467-509.

Marquet $P A$, Santoro CM, Latorre C, Standen VG, Abades SR. 2012. Emergence of social complexity among coastal hunter-gatherers in the Atacama Desert of northern Chile. Proc Natl AcadSci 109:14754-60.

Martinez B. 2012. Gunther von Hagens' Plastination Technique. Embryo Project Encyclopedia URL: https://embryo.asu.edu/ handle/10776/3947 (Accessed July 2020).

McKone HT. 1999. Embalming - chemistry for eternity. Chem Matters 17: 12-13.

Ofusori DA, Ayoka AO, Adeeyo OA, Adewole SO. 2009. Mixture of Kerosene and Xylene: a contribution to clearing agents. International Journal of Morphology 27: 211-18.

Piombino-Mascali D, Aufderheide AC, JohnsonWilliams M, Zink AR. 2009. The Salafia method rediscovered. Virchows Arch 454:355-57.

Seiple J. 2009. Instructor of Embalming at Gupton-Jones College of Funeral Service. Personal interview conducted Sept 42009. URL:https://science.howstuffworks.com/science -vs-myth/afterlife/embalming6.htm (Accessed July 2020). 
Sharquie KE, Najim RA. 2004. Embalming with honey. Saudi Med J 25:1755-56.

Staff E. 2013. History of Embalming and Restorative Arts. Funeral.EliteCME.com, 83-85. URL: https://s3.amazonaws.com > EliteCME WebSite_2013 > pdf (Accessed February 2021). Stapountzis H, Tzavellas P, Moros T. 1991. Effects of Turbulence on the Mixing and
Chemical Reaction for Cross Flow and Coflowing jets. In: Johansson A.V., Alfredsson P.H. (eds) Advances in Turbulence 3. Springer, Berlin, Heidelberg, 300-11.

Trompette P, Lemonnier M. 2009. Funeral embalming: the transformation of a medical innovation. Sci Stud 22: 9-30. 